UDC 621.793:620.179.1/.186

\author{
C. Escobar, J. C. Caicedo*(Cali, Colombia) \\ H. H. Caicedo (PA, Chicago, USA) \\ M. Mozafari (Tehran, Iran) \\ *jcaicedoangulo1@gmail.com
}

\title{
Design of hard surfaces with metal (Hf/V) nitride multinanolayers
}

Physical properties as mechanical and tribological evolution on 4140 steel surfaces coated with hafnium nitride/vanadium nitride $[H f N / V N]_{n}$ multinanolayered systems deposited in various bilayer periods via magnetron sputtering has been exhaustively studied in this work. The coatings have been characterized in terms of structural, chemical, morphological, mechanical, and tribological properties by X-ray diffraction, X-ray photoelectron spectroscopy, atomic force microscopy, scanning and transmission electron microscopies, nanoindentation, pin-on-disc and scratch tests. Moreover, the failure mode mechanisms were observed via scanning electron microscopy. The preferential growth in the face-centered cubic (111) crystal structure for $[\mathrm{HfN} / V \mathrm{~N}]_{n}$ multilayered coatings have been shown by X-ray diffraction results. The best enhancement of the mechanical behavior has been obtained when the bilayer period was $15 \mathrm{~nm}(n=80)$, yielding the highest hardness $(37 \mathrm{GPa})$ and elastic modulus was (351 GPa). The values of the hardness and elastic modulus were 1.48 and 1.32 times higher than the coating with $n=1$, respectively, as well as the lowest friction coefficient $(\sim 0.15)$ and the highest critical load $(72 N)$. These results indicated significant enhancements in mechanical, tribological, and adhesion properties, compared to $H f N / V N$ multilayered systems with bilayer period of $1200 \mathrm{~nm}(n=1)$. The hardness and toughness enhancement in the multilayered coatings could be attributed to the different mechanisms that produce the layer formation with nanometric thickness due to the number of interfaces acting as obstacles for crack deflection and dissipation of crack energy. Due to the emergent characteristics of the synthesized multinanolayered material, the developed adaptive coating could be considered as higher ordered tool machining systems, capable of sustaining extreme operating conditions for industrial applications.

Keywords: hard coatings, isostructural systems, multinanolayers,

tool wear.

\section{INTRODUCTION}

Superior mechanical properties like extreme hardness and good wear resistance have been frequently reported [1-3]. Thus, during recent years transition metal nitride have developed crucial roles in applications where these properties are required. Control of the microstructural and surface morphological evolution of polycrystalline transition metal nitride films is essential for the performance and lifetime of coated tools. Many transition metal nitrides such as titanium nitride/vanadium nitride (TiN/VN), titanium nitride/niobium nitride (TiN/NbN), and tungsten/tungsten nitride (W/WN) with excellent mechanical properties have been studied $[4,5]$. The growth rate of such multilayered structures with nanometer-scale dimensions has attracted much attention from the scientific 
and industrial community. These coatings, now called heterostructures, such as silicon nitride/titanium nitride $\left(\mathrm{a}-\mathrm{Si}_{3} \mathrm{~N}_{4} / \mathrm{nc}-\mathrm{TiN}\right)$, or titanium aluminum nitride/silicon nitride (TiAlN/SiN ${ }_{x}$ ) coatings, exhibit a relatively-high hardness $(\sim 40 \mathrm{GPa})$ and offer potential advantages for dry milling, drilling, and turning [6, 7]. It has been reported that other bilayer combinations such as chromium nitride/tungsten nitride $(\mathrm{CrN} / \mathrm{WN})$ or titanium nitride/niobium nitride $(\mathrm{TiN} / \mathrm{NbN})$, whose maximum hardness values do not exceed $30 \mathrm{GPa}$, are still interesting for mechanical applications. Moreover, new tribological and physicochemical properties like very low friction coefficient and anticorrosive properties are now widely studied [7-9]. However, very few reports persist in the literature about mechanical and tribological responses in nanostructured systems based on isostructural assembly from nitride coatings generated by transition metals. Therefore, the benefits of HfN/VN multilayer system were tested under extreme conditions of corrosion [10], but have not yet been tested at extreme conditions of mechanical performance.

This work evaluated the influence of hafnium nitride/vanadium nitride (HfN/VN) multilayered coatings deposited onto silicon (100) and AISI 4140 steel substrates (most frequently used in the water industry) with different bilayer periods $(\Lambda)$ and bilayer numbers $(n)$ on their physical nature compared to uncoated and coated substrate with HfN, VN single layers. The results indicated that this class of coating could be effectively used for surface applications in industrial factories under processes with aggressive environments. For this purpose, silicon and AISI 4140 steel substrates were coated with a set of HfN/VN multilayers with $\Lambda$ between $1200 \mathrm{~nm}$ and $15 \mathrm{~nm}$ and $n$ between 1 and 80, with a total thickness of $1.2 \mu \mathrm{m}$.

\section{EXPERIMENTAL}

\section{Coating deposition}

Metal (Hf/V) nitride multinanolayered coatings were deposited onto silicon (100) and AISI 4140 steel substrates by using a multi-target rf magnetron sputtering system with an $\mathrm{rf}$ source $(13.56 \mathrm{MHz})$ to apply a negative voltage bias on the substrate and two $\mathrm{Hf}$ and V 4-in. diameter targets with $99.9 \%$ purity. A $350 \mathrm{~W}$ magnetron power was applied to the hafnium target, while a power of $400 \mathrm{~W}$ was applied to the vanadium target. The deposition chamber was initially pumped down to less than $5 \cdot 10^{-6}$ mbar by using a turbomolecular pump, and then a mixture of $(80 \%)$ for Ar gas and $(20 \%)$ for $\mathrm{N}_{2}$ gas was introduced into the chamber. An rf negative bias voltage of $-30 \mathrm{~V}$ was used; the substrate temperature was around $250{ }^{\circ} \mathrm{C}$ and the substrate-to-target distance was $7 \mathrm{~cm}$ for both coatings. During the growth process, the chamber pressure was maintained at $2 \cdot 10^{-3}$ mbar. For multilayered depositions, the hafnium and vanadium targets were covered periodically with a steel shutter. Before deposition, the targets and substrates were sputtercleaned during a 20-min period. An exhaustive X-ray diffraction (XRD) study was carried out by using a PAN analytical X'Pert PRO diffractometer with $\mathrm{CuK} \alpha$ radiation $(\lambda=1.5406 \AA)$ at Bragg-Brentano configuration $(\theta / 2 \theta)$ in high-angle range. Bilayer periods in multilayers were measured by using low-angle XRD $\theta / 2 \theta$ scans and were compared to those obtained from micrographs of transmission electron microscopy (TEM). Microstructural analysis of the multilayers was mainly performed by TEM, using a Philips CM30 microscope operating at $300 \mathrm{kV}$. The ratio between the thicknesses of $\mathrm{HfN}$ and $\mathrm{VN}$ single layers was obtained by means of a (Dektak 3030) Profilometer. Morphologic characteristics of the coatings like grain size and roughness were obtained by using atomic force microscopy (AFM) under contact mode from Asylum Research MFP-3D ${ }^{\mathbb{B}}$ and calculated by a Scanning 
Probe Image Processor $\left(\right.$ SPIP $\left.^{\circledR}\right)$. In this work, SPIP ${ }^{\circledR}$ was used in the grain size analysis for a quantitative study of the grains and particles, and in the roughness analysis for an advanced measurement of the surface roughness. Surface characteristics were determined by scanning electron microscopy (SEM, Phenom FEI) with a magnification range from $525 \times$ to $24.000 \times$ and a high-sensibility detector (multimode) for scattering electrons. To determine the chemical composition, an exhaustive X-ray photoelectron spectroscopy (XPS) study was carried out for HfN/VN multilayered coatings. Thus, XPS was used to analyze the bonding of hafnium, vanadium, and nitrogen atoms by using ESCAPHI 5500 monochromatic $\mathrm{Al} K \alpha$ radiation and a passing energy of $0.1 \mathrm{eV}$. As the surface sensitivity of this technique is so high, any contamination can produce deviations from the real chemical composition. Therefore, the XPS analysis is typically carried out under ultra-high vacuum conditions with a sputter cleaning source to remove any undesired contaminants. Physical analyses as mechanical were performed by nanoindentations using an Ubil-Hysitron device and a diamond Berkovich tip at variable loads. These results were evaluated using the Oliver-Pharr method. Tribological characterization was performed by means of Microtest, MT 400-98 tribometer, using a 6$\mathrm{mm}$ diameter $100 \mathrm{Cr} 6$ steel ball like pattern slide. The applied load was $0.5 \mathrm{~N}$ with a total running length of $1000 \mathrm{~m}$. Adherence of the layers was studied by using a Scratch Test Microtest MTR2 system. The parameters were a 6-mm scratch length and a raising load of 0-90 N. In addition, a SEM was used to identify the different adherence.

\section{RESULTS AND DISCUSSION}

\section{XRD results}

The HfN/VN multilayered coatings show a thickness approximately of $1.2 \mu \mathrm{m}$. The individual thicknesses varied in function to the bilayer number from $n=1$ to $n=80$, producing layers with thicknesses from $1200 \mathrm{~nm}$ to $15 \mathrm{~nm}$, respectively. Figure 1 shows the high-angle XRD patterns corresponding to the HfN/VN multilayered coating. A clear evolution of the patterns is noted in this set of multilayers as bilayer period is increased. As can be seen in Fig. 1, at large bilayer periods, there is a clear face-centered cubic (fcc) lattice with (111) preferred orientation for $\mathrm{HfN}$ layer and fcc (200) preferred orientation for VN layers (isostructured multilayer). These preferential orientations agree with JCPDS 00-033-0592 (HfN) and JCPDS 00-035-0768 (VN) from ICCD cards. The texture of the HfN layer remains constant in the preferential orientation (111) from $1200 \mathrm{~nm}$ thick films to multilayers with $15 \mathrm{~nm}$ thickness. This behavior suggests the possibility of a quasi cube-oncube epitaxial growth. In the thinnest bilayer pattern $(\Lambda \leq 15 \mathrm{~nm})$, there are still some small contributions of HfN (311) and (222) reflections, but they disappear for a large range of bilayer periods till the thickest period multilayer $(\Lambda \leq 1200 \mathrm{~nm})$, where a great $\mathrm{HfN}$ (111) and a small VN (200) peak appear. On the other hand, the shift of diffraction patterns towards high angles is in relation to the compressive residual stress characteristic for those multilayered systems. Therefore, it is observed that the HfN (111) peak position suffers deviation from the bulk value, indicating possible stress evolution of HfN/VN layers with the bilayer period (see Fig. $1, b$ ). The quasi-relaxed position observed for thinner bilayer periods was progressively shifted to the higher compressive stress values as the bilayer period increased until the $\Lambda=1200 \mathrm{~nm}$ value. For thinner multilayered periods $(n=80, \Lambda=$ $15 \mathrm{~nm}$ ), a continuous transition of HfN (111) peak position was observed, from multilayered films with bilayer periods of $120 \mathrm{~nm}$ to those with $15 \mathrm{~nm}$ bilayer pe- 
riod, presenting a stress relief due to the movement of this peak towards higher angles compared to other multilayers, but close to the bulk value $\left(34.01^{\circ}\right)$.
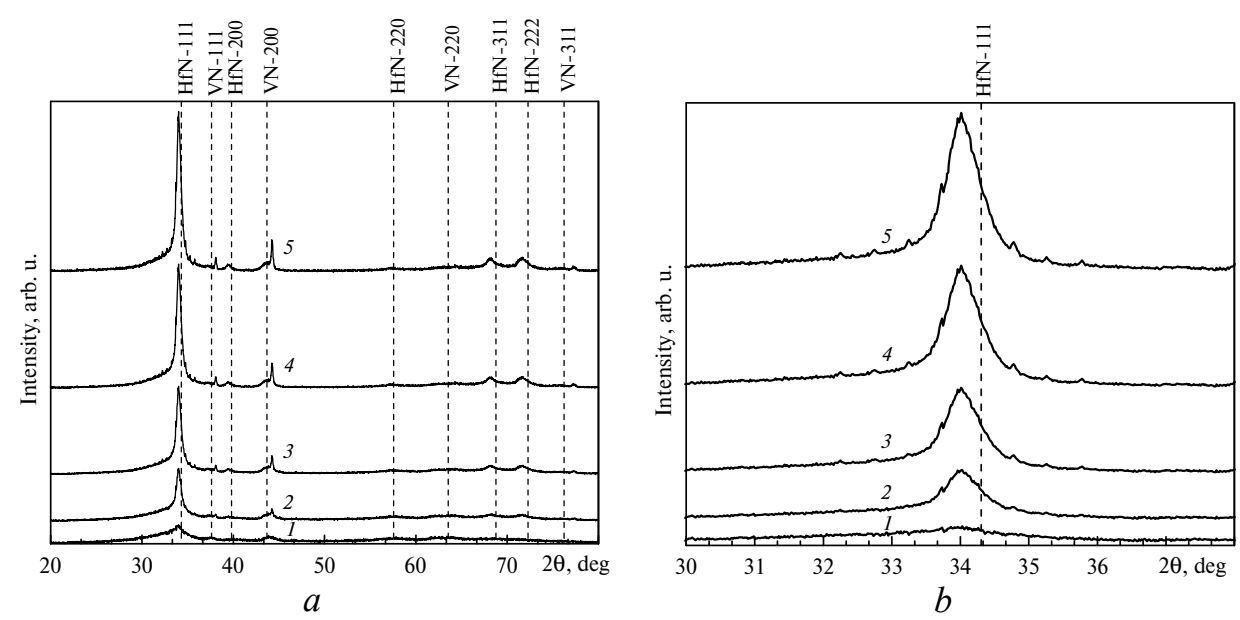

Fig. 1. (a) XRD patterns of the HfN/VN multilayered coatings deposited on the silicon (100) substrates with $\Lambda$ between 1200 and $15 \mathrm{~nm}$ and $n$ between 1 and $80(1-n=1, \Lambda=1200 \mathrm{~nm} ; 2-$ $n=10, \Lambda=120 \mathrm{~nm} ; 3-n=30, \Lambda=40 \mathrm{~nm} ; 4-\Lambda=24 \mathrm{~nm}, n=50 ; 5-n=80, \Lambda=14 \mathrm{~nm})$. Dash lines indicate the position of the peaks obtained from JCPDS files; $(b)$ shows maximum peak with shift toward high angles in relationship to increasing bilayer number $n$.

\section{XPS results}

The XPS survey spectra for HfN and VN single layers that make up the HfN/VN multilayered coatings are shown in Fig. 2. For HfN material (see Fig. 2, a) the peaks at 523.2, 397.6, 224.8, and $18.4 \mathrm{eV}$ correspond to $\mathrm{O} 1 \mathrm{~s}, \mathrm{~N} 1 \mathrm{~s}, \mathrm{Hf}_{4} \mathrm{~d}_{5}$, and Hf4f binding energies, respectively. The change of binding energy compared to HfN verifies the formation of binary Hf- $\mathrm{N}$ compound. Therefore, calculating the peak area yields an atomic ratio of $\mathrm{Hf}: \mathrm{N}=1.1: 0.9$, similar to the stoichiometry of $\mathrm{Hf}_{1.1} \mathrm{~N}_{0.9}$ [11]. On the other hand, for $\mathrm{VN}$ material (see Fig. 2, $b$ ), the peaks at $630.4,532.0,516.8$, and $397.6 \mathrm{eV}$ correspond to $\mathrm{V} 2 \mathrm{~s}, \mathrm{O} 1 \mathrm{~s}, \mathrm{~V} 2 \mathrm{p}_{3 / 2}$, and $\mathrm{N} 1 \mathrm{~s}$ binding energies, respectively. The change of binding energy compared to $\mathrm{VN}$ verifies the formation of binary $\mathrm{V}-\mathrm{N}$ compounds. Therefore, calculating the peak area yields an atomic ratio of $\mathrm{V}: \mathrm{N}=1.1: 0.9$, similar to the stoichiometry of $\mathrm{V}_{1.2} \mathrm{~N}_{0.8}$ [12].

According to the XPS literature, regarding HfN and VN materials [11, 12], when the peaks are fitted from experimental results, it is necessary first to adjust the $\mathrm{N}$ energy band because it is the element that provides greater reliability for XPS; then, taking this first adjustment as base, the other peaks related to the remaining elements are adjusted. The latter is indispensable due to the characteristic present in these kinds of insulating materials (coatings) with respect to the incident signal; thus, avoiding the uncertainties caused by charging and shifts of the Fermi energy. Thereby, the concentration measurements and identification of the specific bonding configurations for the HfN and VN layers are more reliable. So, the core electronic spectra carry information of the chemical composition and bonding characteristics of the $\mathrm{HfN}$ and $\mathrm{VN}$ films and generate an increase in the reliability of the results. 

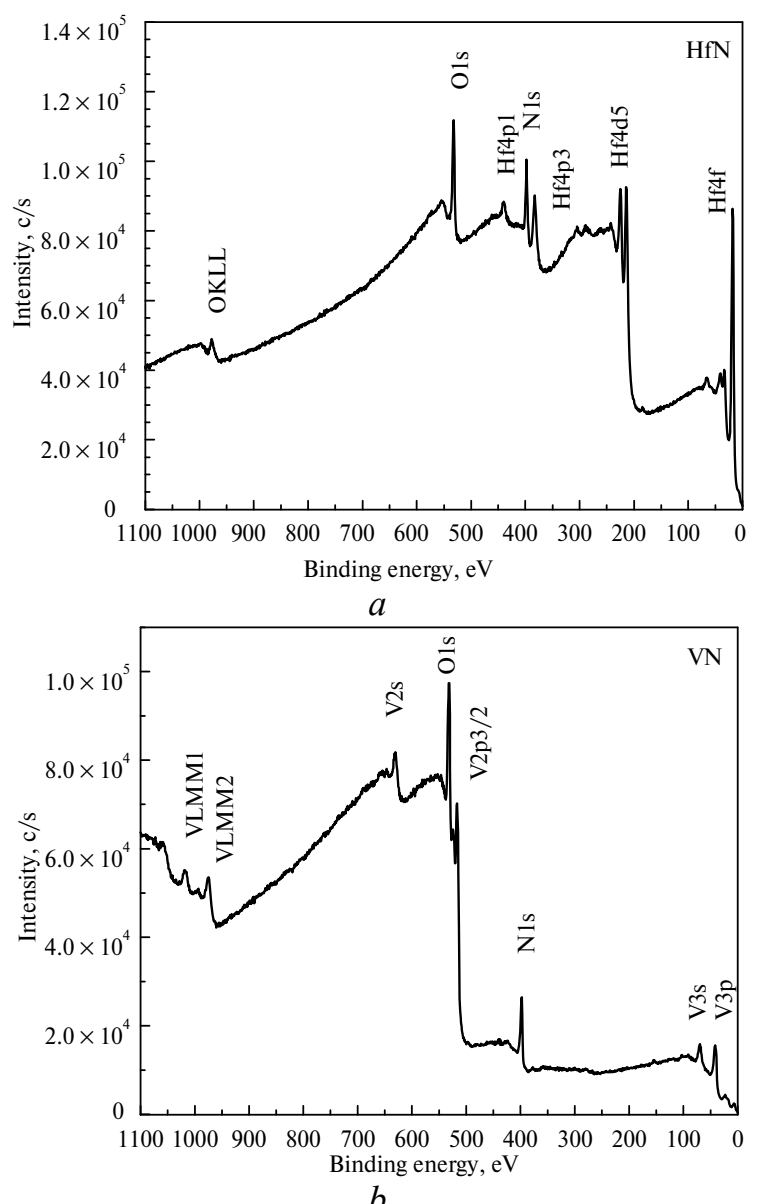

Fig. 2. XPS survey spectrum (a) HfN coatings and (b) VN coatings deposited on the silicon surface with an rf negative bias voltage of $-30 \mathrm{~V}$.

\section{TEM results}

Figure 3 presents the TEM cross-sectional images of an HfN/VN multilayer with $\Lambda=15 \mathrm{~nm}$ ( 80 bilayered). The darkest contrast of HfN layers with respect to those of $\mathrm{VN}$ allowed the clear determination of layer structures. These HfN/VN multilayered coatings presented well-defined and uniform periodicity because the bilayer period in multilayers was confirmed by the TEM analysis. All the multilayer stacks were resolved by TEM and confirmed quite precisely by the previously designed nominal values of bilayer thickness, as well as the total thickness. The TEM images show that VN layers are marginally thicker than those of HfN; they also confirmed that for each multilayer coating there is a different deviation of 0.3 layer thickness ratio. These multilayer modulations were observed when the periodicity on the $\mathrm{HfN} / \mathrm{VN}$ multilayer coating remained constant for the smaller bilayer periods (from $\Lambda=1200$ to $15 \mathrm{~nm}$ ). Moreover, the TEM bright field micrograph in Fig. 3 shows a multilayer with $\Lambda=14 \mathrm{~nm}$, typical of thick bilayer periods. It reveals a compact crystalline structure with wide columnar grains extended along the entire multilayer stack. The selected area electron diffraction (SAED) pattern of the whole multilayer indicated the (111) preferred orientation for an HfN layer and (200) preferred orientation for a VN layer, confirming the structural phenomenon observed by the XRD results. Also, the region shown in Fig. 3 permitted studying 
the structure of a single crystallite, which can be identified as a small dark zone propagating throughout the multilayer. The SAED pattern was taken form a region that overlapping several periods of multilayer structure showing an array of regularly distributed spots (see Fig. 3), confirming together with the XRD results the multilayer structure.

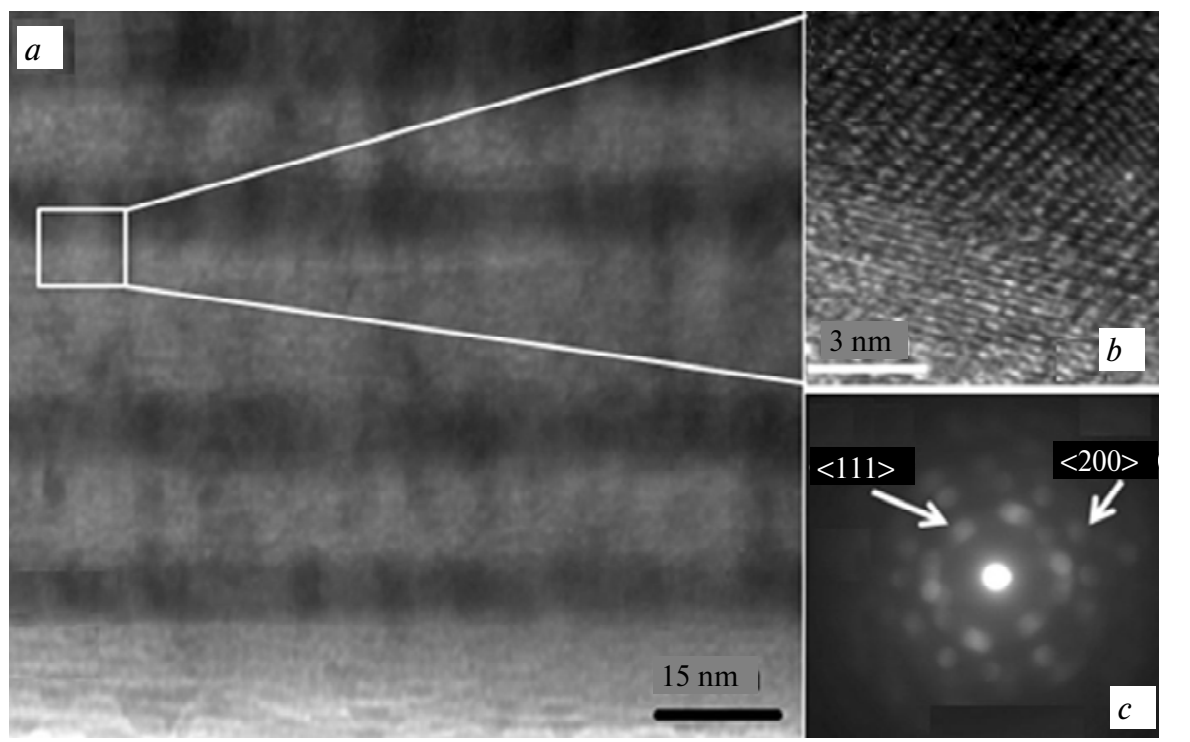

Fig. 3. TEM image of HfN/VN multilayer: ( $a$ ) modulations of HfN/VN coatings with $n=80, \Lambda=$ $15 \mathrm{~nm},(b)$ high resolution TEM (HRTEM) showing multilayer interface, and (c) the SAED pattern taken from a region that overlapping several periods.

\section{AFM results}

The AFM was used to quantitatively study the surface morphology of the samples in relation to decreased bilayer periods or increased bilayer numbers in HfN/VN multilayered coatings deposited onto silicon (100). Figure 4 shows the AFM images for multilayered coatings with statistical distribution of grain size that was analyzed by an area of $1 \times 1 \mu \mathrm{m}$ (AFM images for $(a) n=1,(b) n=10,(c) n=$ $30,(d) n=50$, and $(e) n=80$ ). The correlation between grain size, part $(a)$, and roughness, part $(b)$, with the bilayer number is shown in Figs. 5, $a$ and 5, $b$, respectively.

In Table 1 the quantitative values were extracted from the AFM images by means of statistical analysis scanning probe image processor $\left(\mathrm{SPIP}^{\mathbb{B}}\right)$. The HfN/VN multilayer coating has the same total thickness, around $1.2 \mu \mathrm{m}$. The roughness value was greater for a coating with $n=1$ or high bilayer period $\Lambda=1200 \mathrm{~nm}$, and lower for multilayered coatings with a higher bilayer number $n=80$ or lower bilayer period $\Lambda=15 \mathrm{~nm}$, indicating that coatings with $n=1$ grow more disordered than do multilayered coatings with $n=80$. It has been demonstrated that the grains of the multilayered coatings are smaller than those of coatings with low bilayer period because the $\mathrm{Ar}^{+}$ions bombardment on the coatings stimulates a greater number of nucleation places, given the reduction of individual thicknesses for each layer when the bilayer period is reduced and bilayer numbers are increased. This implicates a decrease in the entire surface roughness [13]. The research took into account that the grain size is affected by changes in grain size of inner layers $(\mathrm{HfN} / \mathrm{VN})$ as a function of reduced bilayer period $\Lambda$ or increased bilayer number $n$. Many authors have reported a correlation between AFM and XRD results [13] 
because AFM analysis delivers surface information (with lateral resolution), and XRD analysis collects information from the space around the normal vector on the surface (from a cross-section). If this is taken into account, it is possible to consider that physical vapor deposition (PVD) coating columns can grow "vertically" from the substrate to the "top" and can change their cross-section when bilayer thickness is modified; therefore, significant changes in the grain size and surface roughness are evident.
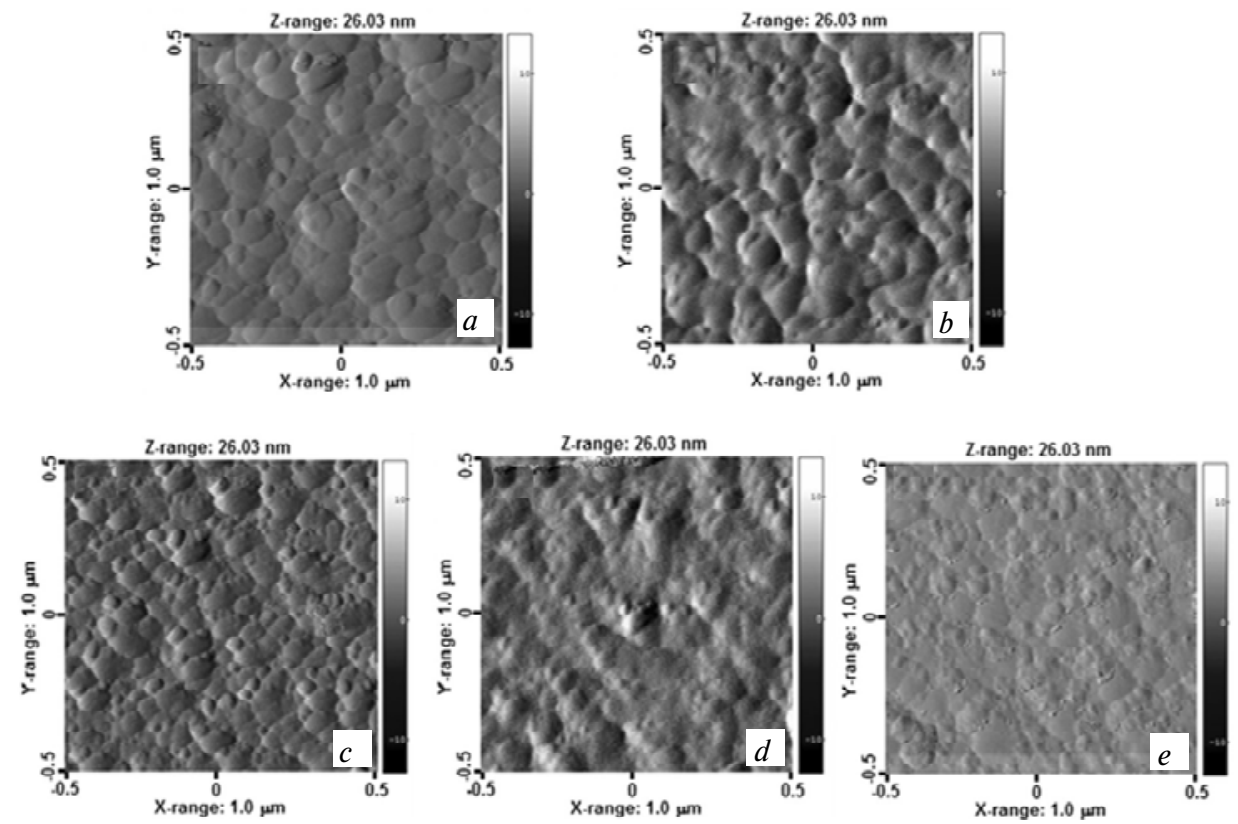

Fig. 4. AFM images for an HfN/VN multilayer grown at rf negative bias voltage of $-30 \mathrm{~V}:(a)$ $n=1,(b) n=10,(c) n=30,(d) n=50, \Lambda=24 \mathrm{~nm}$, and (e) $n=80, \Lambda=15 \mathrm{~nm}$.

Table 1. Surface measurements obtained via AFM and SPIP ${ }^{\circledR}$ analysis for HfN/VN multilayers with a total thickness of $1.2 \mu \mathrm{m}$ and bilayer period from $\Lambda=1200$ to $15 \mathrm{~nm}$ with correlation between bilayer number, grain size, and roughness

\begin{tabular}{c|c|c}
\hline Bilayer number & Grain size, $\mathrm{nm}$ & Roughness, $\mathrm{nm}$ \\
\hline$n=1$ & 78 & 3.9 \\
$n=10$ & 58 & 2.5 \\
$n=30$ & 70 & 1.9 \\
$n=50$ & 56 & 1.3 \\
$n=80$ & 48 & 1 \\
\hline
\end{tabular}

The error in values of grain size and roughness is $\pm 0.1 \mathrm{~nm}$.

\section{Mechanical properties}

Hardness and elastic modulus. It has been frequently reported that the thickness period for many multilayered systems is between 5 and $20 \mathrm{~nm}$, which is relevant for mechanical properties [14]; however, in industrial applications, as mentioned in the introduction, it is necessary to obtain coatings with thicknesses above $\sim 1.0 \mu \mathrm{m}$. Therefore, the multilayer coatings deposited with bilayer period under $20 \mathrm{~nm}$ for a 
total thickness around $\sim 1.2 \mu \mathrm{m}$ imply a complex and extended number of multilayers. Consequently, this study carried out a minimum bilayer period of $15 \mathrm{~nm}$. The typical load-displacement indentation curves of multilayer coatings was conducted by using the standard Berkovich indenter and indentation matrix image by AFM, as shown in Figs. 5, $a$ and 5, $b$. The values of elasticity modulus $(E)$ and hardness $(H)$ were obtained by using the Oliver-Pharr method [15]. The experimental results associated with the mechanical properties correspond to the mixed hardness of the coated systems as a function of the relative indentation depth. As mentioned before, to compare the hardness response of the coatings, the work of indentation models described by Korsunsky et al. [16] was used to analyze the nanoindentation data. This model uses the following equation (Eq. 1) to describe the composite hardness, which is based on the total work done by the indentation load to produce an indentation of depth $(h)$ :

$$
H_{c}=H_{s}+\frac{H_{f}-H_{s}}{1+K \beta^{2}}
$$

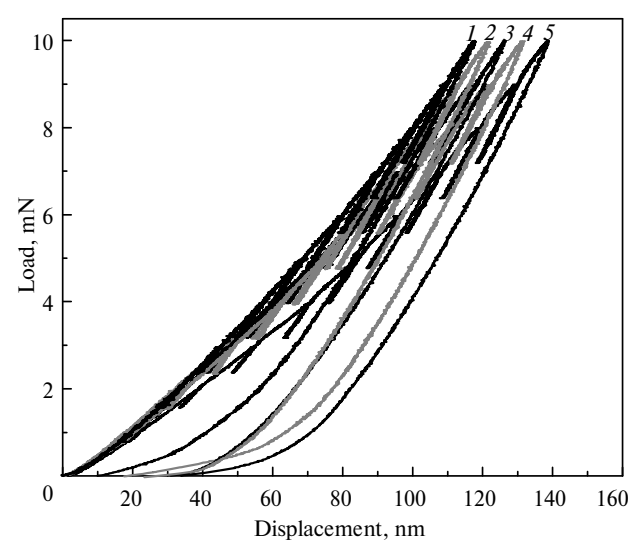

$a$

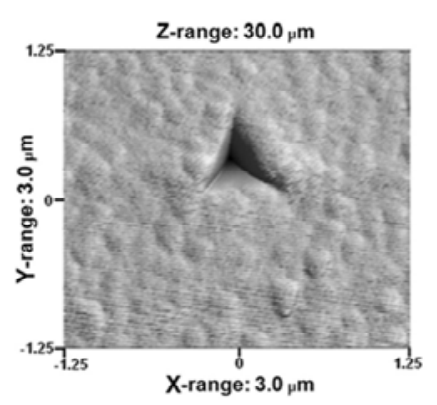

$b$

Fig. 5. Nanoindentation results with (a) load-displacement indentation curves for all coatings $(n=1, \Lambda=1200 \mathrm{~nm}(1), n=10, \Lambda=120 \mathrm{~nm}$ (2), $n=30, \Lambda=40 \mathrm{~nm}$ (3), $n=50, \Lambda=24 \mathrm{~nm}$ (4), and $n=80, \Lambda=15 \mathrm{~nm}(5))$, and (b) the typical indentation track image via AFM for a multilayer with $\Lambda=24 \mathrm{~nm}$ and $n=50$.

In this model $H_{c}$ is the apparent composite hardness, $H_{f}$ is the intrinsic film hardness, $H_{s}$ is the substrate hardness, $k$ is a dimensionless parameter related to the composite response mode to indentation and $\beta=h / t$, which denotes the relative indentation depth with respect to the coating thickness, where $h$ is the maximum indentation depth and $t$ is the coating thickness. The fitting results by applying the work of the indentation model to the experimental data of the HfN/VN multilayer coatings are shown in Fig. 6. The reduced elastic modulus here was determined from nanoindentation measurements, considering the values related to $10 \%$ of the thickness of the coatings.

Normalized relative indentation depth $(\beta=h / t)$ against hardness measured for the $\mathrm{HfN} / \mathrm{VN}$ multilayered coatings, prepared with different bilayer periods is shown in Fig. 6. All the curves presented in Fig. 6 show a decrease in the composite hardness when increasing the penetration depth, which is not surprising because the hardness of AISI 4140 steel in all cases is lower ( $~ 5 \mathrm{GPa})$ than the coated substrates. The hardness value of the HfN/VN sample with $n=80$ is clearly higher than that of $\mathrm{HfN} / \mathrm{VN}$ multilayered coatings with $n$ at 1, 10,30, and 50. The greatest 
hardness of the multilayer set, $37 \mathrm{GPa}$, was obtained for the thinnest bilayer period $(\Lambda=15 \mathrm{~nm})$. Therefore, it was 48 and $43 \%$ greater than the values for the $\mathrm{HfN}$ and VN single-layer coatings, respectively. This effect is probable and attributed to many interfaces that blocking dislocations at the interfaces between $\mathrm{HfN}$ and VN layers due to the differences in the shear module of the individual layer materials, as well as by coherency strains causing periodical strain-stress fields for latticemismatched multilayered coatings [17]. According to Ipaz et al. [18], another condition to enhance the hardness of multilayered coatings with respect to the single layer coating can be associated with the discrete nature of the multilayers and the increased number of interfaces, which is also shown in this study by TEM analyses (see Fig. 3). The enhancement of mechanical properties for HfN/VN multilayers results from the increment of hardness values, as shown in multilayer-type coatings for diverse material systems (e.g., TiN/VN, TiCN/TiNbCN, and $\mathrm{TiC} / \mathrm{TiB}_{2}$ ) [7, 13, 19].

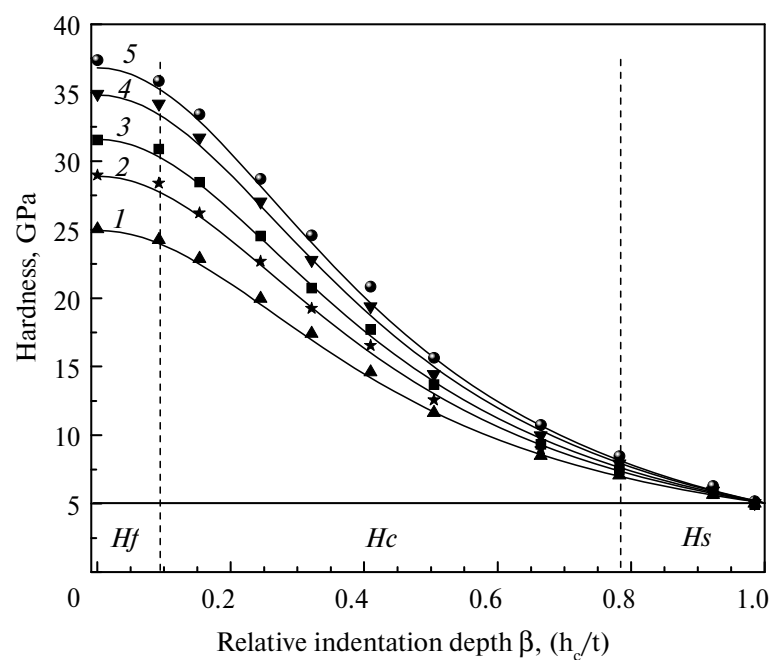

Fig. 6. Relative indentation depths against hardness measured for $\mathrm{HfN} / \mathrm{VN}$ multilayered coatings, as a function of the bilayer number $n$. Continuous lines correspond to the fitting of Eq. (1): $n=1$, $\Lambda=1200 \mathrm{~nm}(1), n=10, \Lambda=120 \mathrm{~nm}(2), n=30, \Lambda=40 \mathrm{~nm} \mathrm{(3),} n=50, \Lambda=24 \mathrm{~nm}(4)$, and $n=$ $80, \Lambda=15 \mathrm{~nm}(5)$.

The $H$ values of the HfN/VN multilayered coatings measured by nanoindentation results (see Figs. 5 and 6 ) are presented in the Table 2 as functions of bilayer period $\Lambda$ and bilayer number $n$. The $E$ values of the multilayered coatings are also presented in Fig. 6, showing the relevant differences in their values. The $H$ and $E$ in these multilayered coatings varied from 25 to $37 \mathrm{GPa}$ and from 265 to $352 \mathrm{GPa}$, respectively. The highest hardness of the multilayer set, $37 \mathrm{GPa}$, was obtained by the thinnest bilayer period $\Lambda=15 \mathrm{~nm}$ and it was 76 and $94 \%$ greater than the expected reference value from the rule-of-mixtures applied to $\mathrm{VN}$ and $\mathrm{HfN}$ singlelayer films, respectively. This increase in the mechanical properties is related to the remarkable heterostructure effects when a perfect assembly occurs for HfN and VN coatings deposited over an industrial AISI 4140 steel substrate. The mechanical properties enhancement can be associated with the improved hardness by using HfN/VN nanometric multilayered materials. Many authors have used the HallPetch effect to explain the material hardening [2, 13, 20]. Therefore, it is possible to apply the Hall-Petch effect when the ceramic materials, as hard multilayered coatings with $\Lambda>5.2 \mathrm{~nm}$, are obtained. Since the multilayered coatings with lower 
$\Lambda$ are within the nanoscale regime, the dislocations should not occur in nanoscale structures below certain grain size values [21].

Table 2. Mechanical properties for HfN/VN multilayered coatings with $\Lambda=$ from $1200 \mathrm{~nm}$ to $15 \mathrm{~nm}$, showing the values of hardness and elastic modulus as a function of bilayer number $n$

\begin{tabular}{c|c|c}
\hline Bilayer number & Hardness, GPa & Elastic modulus, GPa \\
\hline HfN single layer & 19 & 205 \\
VN single layer & 21 & 223 \\
$n=1$ & 25 & 265 \\
$n=10$ & 29 & 289 \\
$n=30$ & 32 & 311 \\
$n=50$ & 35 & 334 \\
$n=80$ & 37 & 352 \\
\hline
\end{tabular}

The error in values of hardness and elastic modulus is $\pm 2 \mathrm{GPa}$.

The hardness value for the HfN/VN coatings is in relation to the reduction of the modulation period (see Fig. 3,a). Therefore, from the nanoindentation results (see Fig. 6), it is possible to observe that indentation test exhibits low deformation size, as the mechanical properties enhance as a function of bilayer number. It is argued that there are some correlations between the hardness of the multilayered coatings and the modulation period [13]. Hence, the hardness enhancement of $\mathrm{HfN} / \mathrm{VN}$ coatings is related to the evidence of a stress relieving according to the distance decrease of interfaces, as shown in the XRD (see Fig. 1) and TEM results (see Fig. 3). Moreover, this mechanical effect was attributed to many interfaces blocking the dislocation movement across the interfaces between the HfN layer and the VN layer due to the differences in the shear moduli of the individual layer materials, and to the coherency strain, causing periodical strain-stress fields $\left(-\sigma_{\mathrm{HfN}}+\sigma_{\mathrm{VN}}\right)$ in the case of lattice mismatched multilayered coatings. Each interface also functions as a grain boundary in a Hall-Petch [2, 20, 21] related mechanism like that of the dislocation pile-up that offers a strong interaction again with interfaces in general. Therefore, each interface serves as a crack tip deflector, which improves the mechanical properties of coating [22]. According to Kim et al. [23], another condition to enhance the hardness of multilayered coatings, with respect to the single-layer coating, is that a layer in the multilayered system has to be discrete, which was found in this study via TEM analyses (see Fig. 2). Also, the enhancement of mechanical properties for an $\mathrm{HfN} / \mathrm{VN}$ multilayer is related to the increased hardness, as shown in many multilayered-type coating systems (e.g., TiN/VN, TiCN/TiNbCN, and $\mathrm{TiC} / \mathrm{TiB}_{2}$ ) [7, 13, 20]. Yashar et al. [2] used a HallPetch approach to model the mechanical behavior of multilayered materials with layer thicknesses as low as $1-100 \mathrm{~nm}$, transforming the Hall-Petch approach into the following equation presented by Caicedo et al., [13]:

$$
H_{m}=H_{f 1+f 2}+k_{I M} D_{t}^{-\frac{1}{2}},
$$

where $H_{m}$ is the multilayer hardness, $H_{f 1+\rho 2}$ is the hardness from layer 1 and layer 2, $k_{I M}$ is a constant measuring the relative hardening contribution of the interface between layer 1 and layer 2 , and $D_{t}$ is the bilayer period $\Lambda$. The model predicts the overall behavior of the hardness on $\Lambda$, observed in most multilayered systems. Previous work has shown that a maximum hardness would be expected when the 
individual components of the multilayer have a relative equal thickness, as presented in this work [24].

Furthermore, it is observed that the elasticity behavior depends on $n$ or $\Lambda$, and the highest bilayer number corresponds to the highest $E$. Therefore, it is concluded that the elasticity and elastic recovery $(R, \%)$ of the multilayered coatings enhance by increasing the interface number. Thereby, from the nanoindentation measurement, the typical values of $E$ and $H$ were obtained by using the Oliver-Pharr method [15]. The $R$ for all HfN/VN multilayered coatings was calculated by the following equation:

$$
R=\frac{\delta_{\max }-\delta_{p}}{\delta_{\max }},
$$

where $\delta_{\max }$ is the maximum displacement and $\delta_{p}$ is the residual or plastic displacement. The equation data were taken from the load-penetration depth curves of indentations for each coating, according to Fig. 5. Table 3 shows an increase in the elastic recovery as a function of bilayer number when $\delta_{\max }$ and $\delta_{p}$ values from load and displacement results (see Fig. 5) are introduced in Eq. (3). Thus, it is possible to observe an interface effect on the multilayered systems, because by increasing the bilayer number $n$ the interface number is increased. Therefore, this can generate an effective hardening characteristic on the multilayered hard coatings, evidenced by an improved elastic recovery. Also, according to Kim et al. [23], a relationship exists between $E$ and $H$, known as the plastic deformation resistance $\left(H^{3} / E^{2}\right)$; this relation was calculated for all the multilayered coatings as a function of bilayer number or bilayer period. Table 3 shows a considerable increase in the resistance to plastic deformation $H^{3} / E^{2}$ as a function of increased bilayer number $n$, which is due to the relation between the increase of interface number and increase of the hardness and the elasticity modulus for all of the multilayered coatings. So, the enhancement in plastic deformation resistance occurs when multilayer period $\Lambda$ decreases, with total thickness constant increasing thus the interface number for coatings. Therefore, the last effect can produce the crystallite refinement, point defect formations, and increasing the interface number; this improves the hardness values of $\mathrm{HfN} / \mathrm{VN}$ multilayered coatings.

Table 3. Elastoplastic properties with plastic deformation for HfN/VN multilayered coatings with bilayer period from $\Lambda=1200$ to $15 \mathrm{~nm}$ : showing the values of $R$, and $H^{3} / E^{2}$ as functions of $n$

\begin{tabular}{ccc}
\hline Bilayer number & Elastic recovery $R, \%$ & Plastic deformation resistance $H^{3} / E^{2}$ \\
\hline HfN single layer & 72 & 0.16 \\
VN single layer & 73 & 0.19 \\
$n=1$ & 75 & 0.22 \\
$n=10$ & 77 & 0.29 \\
$n=30$ & 80 & 0.33 \\
$n=50$ & 87 & 0.38 \\
$n=80$ & 91 & 0.40 \\
\hline
\end{tabular}

As shown in Table 3, the HfN/VN nanometric multilayered coatings increased the plastic deformation resistance and elastic recovery with respect to coatings deposited with lower bilayer numbers. The maximum value was reached for $n=80$ and $\Lambda=15 \mathrm{~nm}$, i.e., plastic deformation due to the applied load is more markedly 
reduced than that of other multilayered systems with fewer bilayer numbers. This effect clearly correlates to increasing coating density, hardness, and elastic recovery [15]. In general, the bilayer number $n$ or bilayer period $\Lambda$ has some effects on the multilayer shown to exhibit very high hardness in nitride multilayered coatings.

\section{Tribological properties}

Pin-on-disk analysis. The friction coefficient values for AISI 4140 steel substrates coated with different multilayered systems $(\Lambda=1200 \mathrm{~mm}, n=1 ; \Lambda=$ $120 \mathrm{~nm}, n=10 ; \Lambda=150 \mathrm{~nm}, n=30 ; \Lambda=40 \mathrm{~nm}, n=50 ; \Lambda=24 \mathrm{~nm}, n=50$; and $\Lambda=15 \mathrm{~nm}, n=80$ ) were tested against steel balls and presented in Fig. 7, $a$. These curves showed two distinct stages. In the first stage, the friction coefficient $(\mu)$ began at a low level $(0.15-0.25)$ in the first contact; this stage can be attributed to the running-in period associated with a kind of contact between the steel ball and the coating, where the formation of wear debris occurs by the cracking of roughness tips on both counterparts. This stage has a short time period, and then the friction coefficient increases to $0.4-0.5$ followed by a decrease to the friction coefficient of the second stage. This stage is defined as the steady-state friction period and begins after about $30-80 \mathrm{~m}$ of sliding distance $(\mathrm{m})$ [19]. Figure 7, $b$ shows the friction coefficient as a function of bilayer numbers. The tribological properties of the homogeneous $\mathrm{HfN}$ and $\mathrm{VN}$ single-layer coatings were provided in Fig. 7 for comparison in relation to multilayered systems. These tribological results showed the reduction of the friction coefficient, while the bilayer number increased and the bilayer period decreased. The friction coefficient of HfN/VN multilayer coatings ranged from approximately 0.33 to 0.15 , being the lowest value reported for the multilayer growth with $\Lambda=15 \mathrm{~nm}$, and $n=80$. The friction coefficient value represented a decrease at approximately 75 and $65 \%$ of the friction coefficient with respect to the $\mathrm{HfN}$ and $\mathrm{VN}$ single layers, respectively. The last behavior can be related to the friction mechanical model proposed by Archard [25], which relates the contribution of the contact surface roughness and the elastic-plastic properties of the coating in the following equation:

$$
\mu=\frac{F_{f}}{F_{n}}=C_{k} \frac{R(s, a)}{\sigma t(H, E)},
$$

where $\mu$ is the friction coefficient, $C_{k}$ is a constant that depends on the parameter of the test, $R(s, a)$ is the coating roughness, and $\sigma t$ is a variable that takes into account the elastic-plastic properties ( $H$ or $E$ ), obtained by mechanical measures [25]. In agreement with the model presented by Archard, when the surface coating has low roughness and high hardness, the friction coefficient will tend to decrease and will be stable for long sliding distances, specifically if the counterpart of the test is softer than the coating. On the other hand, although hardness has long been regarded as a primary material property that defines wear resistance, strong evidences suggest that the elastic modulus can also have an important influence on the wear behavior. In particular, the elastic strain to failure, related to the ratio of $H$ and $E$, which has been shown by a number of authors to be a more suitable parameter to predict wear resistance than the hardness alone. Until now, scientific researches have been mainly aimed at achieving ultrahigh hardness associated with high elastic modulus, the latter of which, conventional fracture mechanics theory would suggest, is also desirable for wear improvement (by preventing crack propagation). This study discusses the concept of multilayered coatings with relatively high hardness and high elastic modulus, which can exhibit improved toughness and are, therefore, better suited to optimize the wear resistance of 'real' industrial sub- 
strate materials (i.e., steels and light alloys with low moduli). Recent advances in the development of ceramic-ceramic $(\mathrm{HfN} / \mathrm{VN})$ multilayer coatings are summarized and discussed in terms of their relevance to practical applications. This paper observed that the elastic strain to failure (which is related to $H^{3} / E^{2}$, see Table 3) affects the tribological behavior of $\mathrm{HfN} / \mathrm{VN}$ multilayered coatings that, although not necessarily exhibiting extreme hardness, provide superior wear resistance when deposited on the substrate materials for industrial applications [26]. Therefore, this behavior suggests that improving plastic deformation resistance when the bilayer number is increased, exerts more wear resistance due to enhanced mechanical properties (see Table 3) associated with the perfect modulation assembly (previously observed in XRD and TEM), thus, generating a
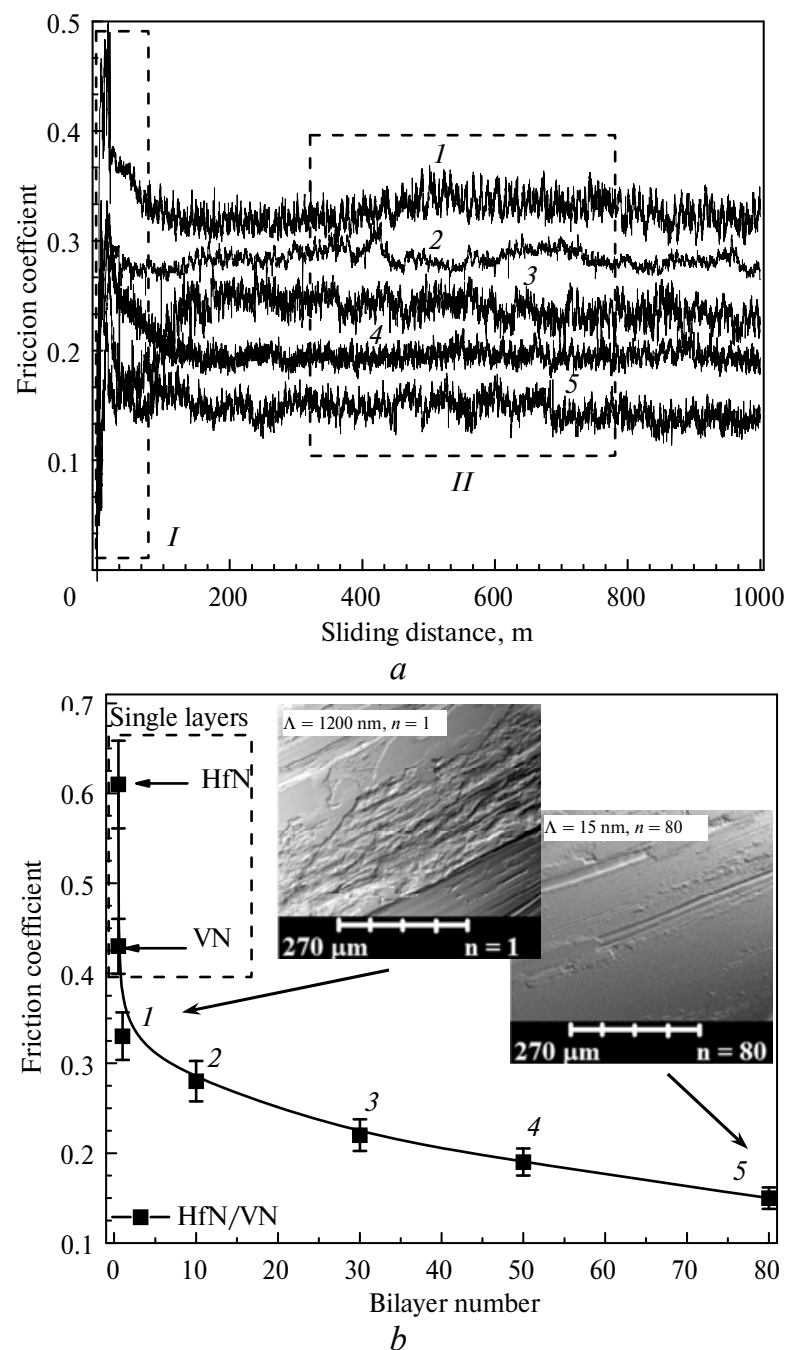

Fig. 7. Tribological results of 4140 steel substrates coated with HfN/VN multilayered systems: (a) friction coefficient as a function of sliding distance and $(b)$ friction coefficient as a function of the bilayer numbers $n$ or bilayer periods $\Lambda$ with wear track observed by SEM: $n=1, \Lambda=$ $1200 \mathrm{~nm}(1), n=10, \Lambda=120 \mathrm{~nm}(2), n=30, \Lambda=40 \mathrm{~nm}(3), n=50, \Lambda=24 \mathrm{~nm}$ (4), and $n=80$, $\Lambda=15 \mathrm{~nm}(5)$. 
reduction in the friction coefficient (see Fig. 7). As can be seen in Fig. 7, $b$ (SEM micrographs), it is possible to find different wear mechanisms, such as abrasion, adhesion, oxidation, and diffusion. In this sense, the abrasion mechanism is a predominant phenomenon at multilayers with low bilayer number (low mechanical properties). The values for multilayer period, at which the maximum wear values occur, will depend on different factors like the combination of high roughness, small grain size, and low elastic modulus, among others.

Adhesion behavior. The scratch test was used to characterize the coating adherence strength. The adhesion properties of single-layer coatings and multilayered coatings can be characterized by the following two terms: $L_{c 1}$, the lower critical load, which is defined as the load where cracks first occurred (cohesive failure); and $L_{c 2}$, the upper critical load, which is the load where the first delaminating at the edge of the scratch track occurred (adhesive failure) [25]. The values of critical load $\left(L_{c 1}\right.$ and $\left.L_{c 2}\right)$ for the different coatings are shown in Fig. 8. The $L_{c 1}$ was shown for the different coatings in the range of $27-58 \mathrm{~N}$, in which the lowest value was attributed to the multilayered coating deposited with $n=1$ and the highest value was attributed to the HfN/VN multilayered coating growth with $\Lambda=15 \mathrm{~nm}$ and $n=$ 80 .

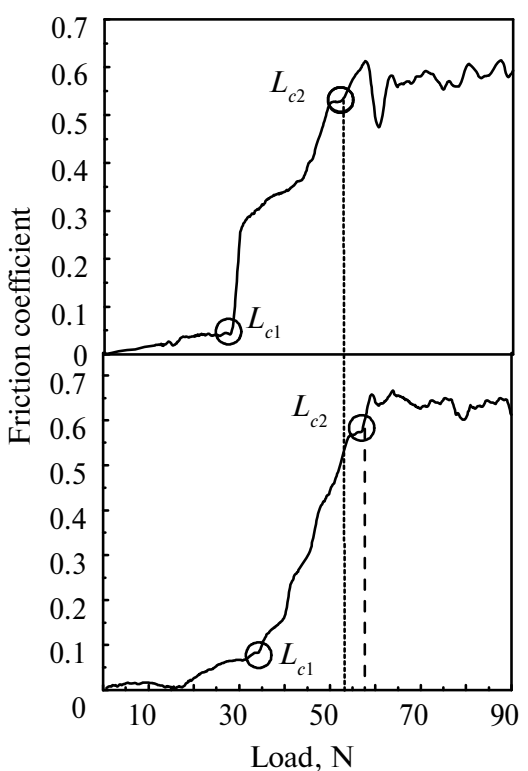

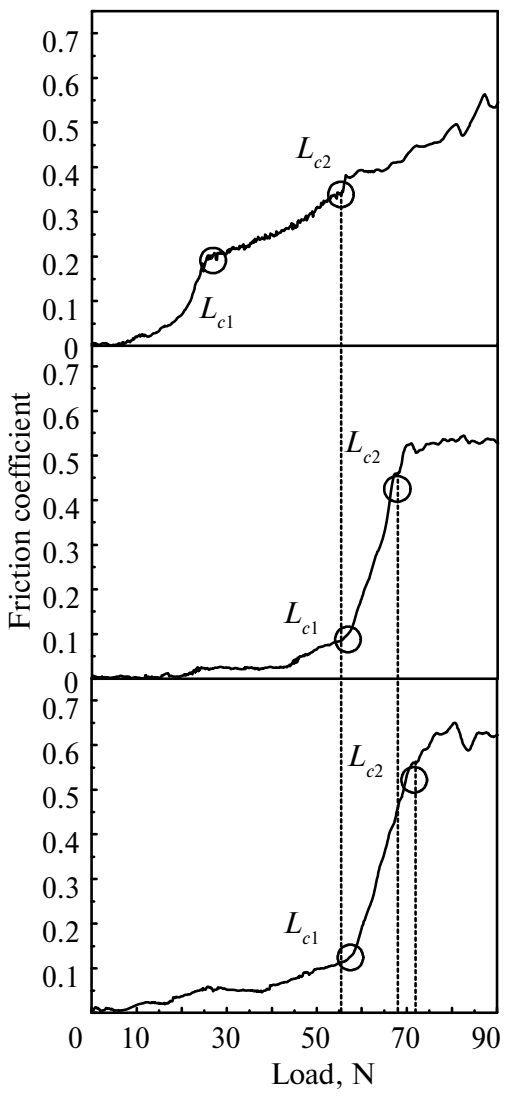

$b$

Fig. 8. Tribological results for friction coefficient curves versus load for HfN/VN multilayered coatings, showing the adhesion failure $\left(L_{c 2}\right):(a) n=1, \Lambda=1200 \mathrm{~nm}(1), n=10, \Lambda=120 \mathrm{~nm}$ (2), (b) $n=30, \Lambda=40 \mathrm{~nm}(3), n=50, \Lambda=24 \mathrm{~nm}$ (4); and $n=80, \Lambda=15 \mathrm{~nm}$ (5); $L_{c 1}$ - cohesive failure, $L_{c 2}$ - adhesive failure.

The critical loads in $L_{c 2}$ values for the different coatings are summarized in Table 4 . This table clearly shows that the adhesion properties of $\mathrm{HfN} / \mathrm{VN}$ multilay- 
ered coatings increase as a function of decrease in bilayer period. Due to the quantitative adhesion measurements between the layers and substrates, this process is complex even for single-layer coatings, which is in agreement with some previously published reports [19]. A qualitative characterization is necessary to evaluate the adhesion behavior of all multilayered systems, as described before in this section, i.e., in terms of $L_{c 1}$ and $L_{c 2}$ critical loads. Therefore, for the purpose of ensuring a fair comparison between the different coating systems, it was assumed that the adhesion between the substrate and the first layer of the multilayered system remains constant (since the preparation conditions and parameters were the same). Besides, in all cases, it was verified that the parameters of the scratch test for all samples were also the same. According to the latter, it was expected that the response to the applied load will only depend on the coating properties because of the effect of each layer and the interfaces that make up the entire multilayered system.

From Table 4, it was observed that the values of critical load increased when bilayer period $\Lambda$ was increased and bilayer number $n$ was increased. This improvement is in part due to the increase in the coating/substrate deformation resistance. In this mechanism, each interface serves as a crack tip deflector that changes the direction of the initial crack when it penetrates deep into the coating, and strengthens the coating performance. Moreover, by decreasing the bilayer period, the dislocations among the layers found a major impediment to moving; therefore, those will require higher critical shear stress to move and spread throughout the coating and allow a delaminating of the coating. This means that multilayered coatings fail in a laminar manner [14] due to the multilayered assembly, as found in the TEM analysis (see Fig. 3). In consequence, multilayered and multiple structures like those studied in this research can enhance the resistance of coatings against crack propagation in relation to the mechanical property evolution presented by the enhanced hardness and elastic modulus (see Table 2) with highest elastic recovery (see Table 4), preserving the integrity of the coatings under punctual and dynamic loads [27]. In this work, it was observed that an increase of $27 \%$ in the $L_{c 2}$ for $\mathrm{HfN} / \mathrm{VN}$ multilayered systems with $\Lambda=15 \mathrm{~nm}$ and $n=80$ is in relation to the multilayers with lowest bilayer number $(n=1)$.

Table 4. Correlation of critical loads $L_{c 2}$ with bilayer numbers $\boldsymbol{n}$ or bilayer periods $\Lambda$

\begin{tabular}{c|c}
\hline Bilayer number & Critical loads $L_{c 2}$ \\
\hline HfN single layer & 34 \\
VN single layer & 41 \\
$n=1$ & 52 \\
$n=10$ & 57 \\
$n=30$ & 64 \\
$n=50$ & 68 \\
$n=80$ & 72 \\
\hline
\end{tabular}

The error in values of critical loads is $\pm 1 \mathrm{~N}$.

\section{Surface tribological results}

Scanning electron microscopies images showing the different behaviors of the multilayered coatings after scratch tests are shown in Figs. 9, $a$ and 9, $b$. These images, revealed that at the beginning of the scratch pronounced deformation ap- 
peared due to the substrate plastic deformation and a coating debris removal, associated with the adhesive layer/substrate failure mechanism sideward lateral flanking [28]; thus, the SEM images confirm the scratch test results observed in Fig. 9.

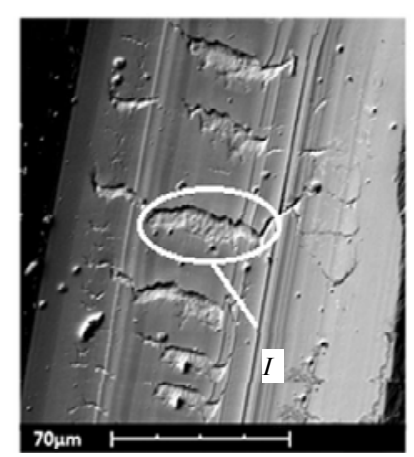

$a$

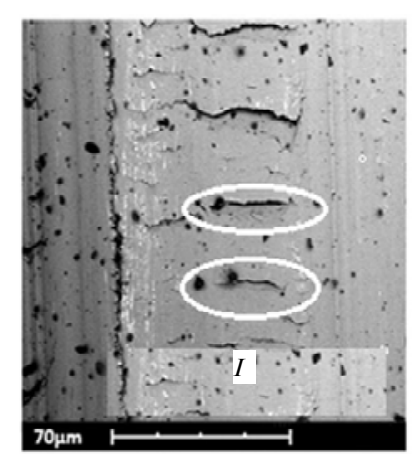

$b$

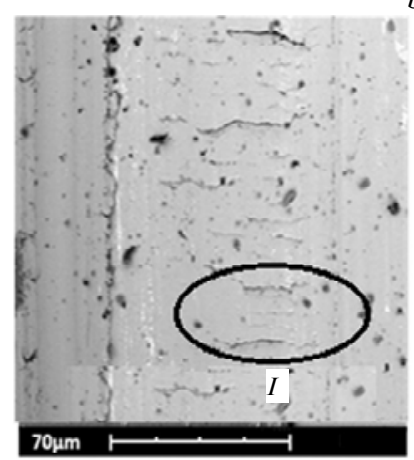

d

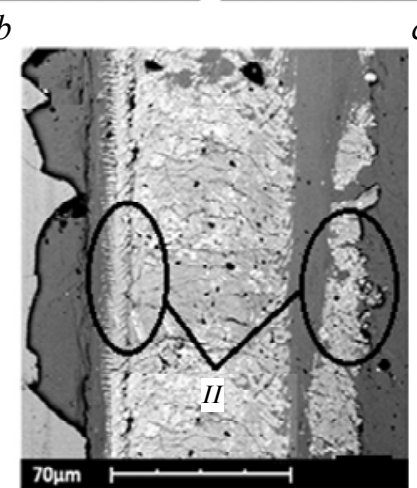

$e$

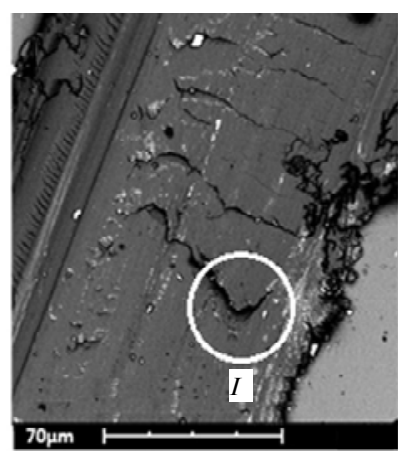

$c$

Fig. 9. SEM micrographs of the scratch tracks on (a) $n=1, \Lambda=1200 \mathrm{~nm}$; (b) $n=10, \Lambda=$ $120 \mathrm{~nm} ;(c) n=30, \Lambda=40 \mathrm{~nm}$; (d) $n=50, \Lambda=24 \mathrm{~nm}$; and (e) $n=80, \Lambda=15 \mathrm{~nm}$, deposited onto industrial AISI 4140 steel; $I$ - buckling cracks; $I I$ - recovery spallation.

Figure 9, $a$ shows a premature adhesion failure due to the accumulation of stress at the scratch edges to the multilayered system deposited with $n=1$ $(\Lambda=1200 \mathrm{~nm})$. Performing a detailed analysis of failure mechanisms for the $[\mathrm{HfN} / \mathrm{VN}]_{80}$ multilayer $(\Lambda=15 \mathrm{~nm})$ at the beginning of the scratch mark, there was a pronounced irregularity due to the plastic deformation of the metal substrates (see Fig. 9, e). Later (furthest from scratch), conformal cracking of the layer associated with adhesive failure $\left(L_{c 2}\right)$ appears. As other multilayered systems $(n=1,10,30$ and 50 ), the systems with 80 bilayers coatings also presented "Recovery Spallation" type wear mechanisms (see Fig. 9,e). These series of multilayers showed a failure behavior type "Buckling Cracks" that is characteristic of protective systems where the substrate is ductile and hard coating have good adhesion between them, these systems generate compressive efforts that are characteristic of cracks buckling failure mode [26].

\section{CONCLUSIONS}

Multilayered structure has been identified as an isostructural multilayer of $\mathrm{HfN}$ and VN phases. The preferential orientation (111) for fcc lattice of $\mathrm{HfN}$ and (200) for fcc lattice of VN single layers has been shown in the XRD patterns. From the XPS results, it has been possible to identify the chemical composition in both single-layer coatings. 
The TEM analysis confirmed well-defined multilayered structures and showed slight variations in layer thickness ratio. The morphology and surface quality have been determined for all coating systems, establishing homogeneous surfaces for all of them. The grains of the multilayers were smaller than those of the individual $\mathrm{HfN}$ and $\mathrm{VN}$ coatings. This fact has been attributed to the ion bombardment of the coatings, which stimulated a greater number of nucleation sites that together with grain size reduction by decreased bilayer period led to the decrease of the entire surface roughness.

It has been found that the highest values of hardness and elastic modulus, $37 \mathrm{GPa}$ and $351 \mathrm{GPa}$, respectively, were observed for multilayered systems with $\Lambda$ $=15 \mathrm{~nm}$ and $n=80$. The enhancement in the hardness value of the HfN/VN stack has been attributed to many interfaces blocking the micro-crack movements across the interfaces between the HfN layer and VN layer due to the differences in the shear module of the individual layer material, and to the coherency strain causing periodical strain-stress fields; together with the Hall-Petch models, which gives a good overall picture of the hardness enhancements.

High tribological performance with critical loads in adhesive failure of $72 \mathrm{~N}$ and friction coefficient of 0.18 have been observed for the multilayered systems with $\Lambda=15 \mathrm{~nm}$ and $n=80$. From the SEM micrographs, it has been determined that for the multilayered coatings different types of adhesive layer/substrate failures appear under strong plastic deformation conditions, which is important for the preparation of wear resistant cutting and forming tools and mechanic devices used in industrial applications.

This research was supported by "El patrimonio Autónomo Fondo Nacional de Financiamiento para la Ciencia, la Tecnología y la Innovación Francisco José de Caldas" under contract RC-No. 275-2011 and the program "Jóvenes Investigadores e Innovadores Virginia Gutiérrez de Pineda No. 525-2011". Moreover, the authors acknowledge the Center of Excellence for Novel Materials (CENM) and, CINVESTAV, Mexico. Moreover, the authors acknowledge the Serveis CientíficoTécnics of the Universitat de Barcelona for XRD, XPS, and TEM analysis.

Фізичні властивості як механічні і трибологічні зміни на поверхні сталі марки 4140 з покриттям із нанобагатошарових систем нітриду гафнію/нітриду ванадію $[\mathrm{HfN} / V N]_{n}$, нанесених магнетронним розпиленням з різними проміжками між двома шарами, були ретельно вивчені в ичій роботі. Структурні, хімічні, морфологічні $і$ трибологічні властивості покриттів визначали дифракцією рентгенівських променів, фотоелектронною рентгенівською спектроскопією, атомно-силовою мікроскопією, растровою та просвічувальною електронною мікроскопією, наноіндентуванням, методом "штифт на крузі” і випробуванням дряпанням. Крім того, механізми відмов спостерігали за допомогою растрової електронної мікроскопї. Результати дифракції рентгенівських променів показали краще зростання (111) граніцентрованої кристалічної структури для багатошарових покриттів [HfN/VN] ${ }_{n}$. Максимальне підвищення механічних характеристик було досягнуто при товщчні бішару $H f N / V N$, щчо дорівнював 15 нм (число шарів 80), твердість складала 37 ГПа, а модуль пружності - 351 ГПа. Ці значення твердості $і$ модуля пружності були вище, ніж у покриття з $n=1$ (в 1,48 i 1,32 рази відповідно), також це багатошарове покриття мало найнижчий ( 0,15) коефіцієнт тертя $і$ найвище (72 H) критичне навантаження. Ці результати показали значне поліпшення механічних, трибологічних і адгезійних властивостей порівняно з HfN/VN багатошарової системою 3 товщиною бімару 1200 нм $(n=1)$. Підвищення твердості і в'язкості руйнування багатошарових покриттів може бути пояснено різними механізмами утворювання шарів нанометричної товщини, зумовлених кількістю меж розділу, щуо діють як перешкоди для відхилення тріщцни і розсіювання ї̈ енергії. Завдяки покращченим характеристикам синтезованого багатошарового матеріалу, розроблене адаптивне покриття можна розглядати як більш високо впорядковану інструментальну систему обробки, здатну підтримувати екстремальні робочі умови при використанні в промисловості. 
Ключові слова: тверде покриття, ізоструктурні системи, мультінаношар, знос інструменту.

Физические свойства как механические и трибологические изменения на поверхности стали марки 4140 с покрытием из наномногослойных систем нитрида гафния/нитрида ванадия [HfN/VN] $]_{n}$ нанесенных магнетронным распылением с различными промежутками между двумя слоями, были тщательно изучены в этой работе. Структурные, химические, морфологические и трибологические свойства покрытий определяли дифракиией рентгеновских лучей, фотоэлектронной рентгеновской спектроскопией, атомно-силовой микроскопией, растровой и просвечивающей электронной микроскопией, наноиндентированием, методом “итифт на круге” и испытания ияарапаньем. Кроме того, механизмы отказов наблюдали посредством растровой электронной микроскопии. Результаты дифракции рентгеновских лучей показали предпочтительный рост (111) гранецентрированной кристаллической структуры для многослойных покрытий $[H f N / V N]_{n}$. Максимальное повышение механических характеристик было достигнуто при толщине бислоя HfN/VN равной 15 нм (число слоев 80), твердость была равна 37 ГПа, а модуль упругости - 351 ГПа. Эти значения твердости и модуля упругости были выше, чем у покрытия с $n=1$ (в 1,48 и 1,32 раза соответственно), также у этого многослойного покрытия был самый низкий $(\sim 0,15)$ коэффициент трения и самая высокая (72 H) критическая нагрузка. Эти результаты показали значительное улучшение механических, трибологических и адгезионных свойств по сравнению с HfN/VN многослойной системой с толщиной бислоя 1200 нм $(n=1)$. Повышение твердости и вязкости разрушения многослойных покрытий может быть объяснено различными механизмами образования слоев нанометрической толщины, обусловленных количеством границ раздела, действующих как препятствия для отклонения трещины и рассеяния ее энергии. Благодаря улучшенным характеристикам синтезированного многонанослойного материала, разработанное адаптивное покрытие можно рассматривать как более высоко упорядоченную инструментальную обрабатывающую систему, способную поддерживать экстремальные рабочие условия при использовании в промыиленности.

Ключевые слова: твердое покрытие, изоструктурные системы, мультинанослой, износ инструмента.

1. Ghosh S. K., Limaye P. K., Swain B. P. et al. Tribological behavior and residual stress of electrodeposited $\mathrm{Ni} / \mathrm{Cu}$ multilayer films on stainless steel substrate // Surf. Coat. Tech. 2007. - 201. - P. 4609-4618.

2. Barshilia H. C., Jain A., Rajam K. S. Structure, hardness and thermal stability of nanolayered TiN/CrN multilayer coatings // Vacuum. - 2003. - 72. - P. 241-248.

3. Morant C., Cáceres D., Sanz J. M., Elizalde E. Nano-mechanical properties of BCN/CN/BN multilayer films // Diamond Relat. Mater. - 2007. - 16. - P. 1441-1444.

4. Kim S. Analysis of interfacial strengthening from composite hardness of TiN/VN and TiN/NbN multilayer hard coatings // Surf. Coat. Tech. - 2004. - 187. - P. 47-53.

5. Wu F.-B., Tien S.-K., Duh J.-G. Manufacture, microstructure and mechanical properties of $\mathrm{CrWN}$ and $\mathrm{CrN} / \mathrm{WN}$ nanolayered coatings // Ibid. - 2005. - 200. - P. 1514-1518.

6. Chan Y.-C., Chen H.-W., Chao P.-S. et al. Microstructure control in TiAlN/SiNx multilayers with appropriate thickness ratios for improvement of hardness and anticorrosion characteristics // Vacuum. - 2013. - 87. - P. 195-199.

7. Yu L., Dong S., Xu J., Kojima I. Microstructure and hardening mechanisms in a-Si $\mathrm{Si}_{3} / \mathrm{nc}-\mathrm{TiN}$ nanostructured multilayers // Thin Solid Films. - 2008. - 516. - P. 1864-1870.

8. Nordin M., Larsson M., Hogmark S. Mechanical and tribological properties of multilayered PVD TiN/CrN, TiN/MoN, TiN/NbN and TiN/TaN coatings on cemented carbide // Surf. Coat. Tech. - 1998. - 106. - P. 234-241.

9. Tsai Y.-Z., Duh J.-G. Tribological behavior of CrN/WN multilayer coatings grown by ionbeam assisted deposition // Ibid. - 2006. - 201. - P. 4266-4272.

10. Escobar C., Villarreal M., Caicedo J. C. et al. Novel performance in physical and corrosion resistance HfN/VN coating system // Ibid. - 2013. - 221. - P. 182-190.

11. Arranz A. Synthesis of hafnium nitride films by $0.5-5 \mathrm{keV}$ nitrogen implantation of metallic Hf: an X-ray photoelectron spectroscopy and factor analysis study // Surf. Sci. - 2004. - 563. - P. 1-12. 
12. Glaser A., Surnev S., Ramsey M. G. et al. The growth of epitaxial VN (111) nanolayer surfaces // Ibid. - 2007. - 601. - P. 4817-4823.

13. Caicedo J. C., Amaya C., Yate L. et al. TiCN/TiNbCN multilayer coatings with enhanced mechanical properties // Appl. Surf. Sci. - 2010. - 256. - P. 5898-5904.

14. Stueber M., Holleck H., Leiste H. et al. Concepts for the design of advanced nanoscale PVD multilayer protective thin films // J. Alloy. Compd. - 2009. - 483. - P. 321-333.

15. Oliver W.C., Pharr G. M. An improved technique for determining hardness and elastic modulus using load and displacement sensing indentation experiments // J. Mater. Res. 1992. - 7. - P. 1564-1583.

16. Korsunsky A. M., McGurk M. R. et al. On the hardness of coated systems // Surf. Coat. Tech. - 1998. - 99. - P. 171-183.

17. Jehn H. A. Improvement of the corrosion resistance of PVD hard coating-substrate systems // Ibid. - 2000. - 125. - P. 212-217.

18. Ipaz L., Caicedo J. C., Esteve J. et al. Improvement of mechanical and tribological properties in steel surfaces by using titanium-aluminum/titanium-aluminum nitride multilayered system // Appl. Surf. Sci. - 2012. - 258. - P. 3805- 3814.

19. Holleck H., Lahres M., Woll P. Multilayer coatings-influence of fabrication parameters on constitution and properties // Surf. Coat. Tech. - 1990. - 41. - P. 179-190.

20. Yashar P. C., Sproul W. D. Nanometer scale multilayered hard coatings // Vacuum. - 1999. 55. - P. 179-190.

21. Park J.-K., Baik Y.-J. The crystalline structure, hardness and thermal stability of AlN/CrN superlattice coating prepared by D.C. magnetron sputtering // Surf. Coat. Tech. - 2005. - 200. - P. 1519-1523.

22. Wang X. C., Mi W. B., Jiang E. Y., Bai H. L. Structure and mechanical properties of titanium nitride/carbon nitride multilayers // Appl. Surf. Sci. - 2009. - 255. - P. 4005-4010.

23. Kim G. S., Lee S. Y., Hahn J. H. Synthesis of CrN/AlN superlattice coatings using closedfield unbalanced magnetron sputtering process // Surf. Coat. Tech. - 2002. - 171. - P. 91-95.

24. Lewis D. B., Wadsworth I., Mu W. et al. Structure and stress of TiAlN/CrN superlattice coatings as a function of $\mathrm{CrN}$ layer thickness // Ibid. - 1999. - 116-119. - P. 284-291.

25. Archard J. F. Contact and Rubbing of Flat Surfaces // J. Appl. Phys. - 1953. - 24, N 8. P. 981-987.

26. Leyland A., Matthews $A$. On the significance of the $H / E$ ratio in wear control: a nanocomposite coating approach to optimized tribological behavior // Wear. - 2000 - 246. - P. 1-11.

27. Podgornik B., Hogmark S., Sandberg O., Leskovsek V. Wear resistance and anti-sticking properties of duplex treated forming tool steel // Ibid. - 2003. - 254. - P. 1113-1121.

28. Holmberg K., Ronkainen H., Matthews A. Tribology of thin coatings // Ceram. Int. - 2000. 26. - P. 787-795.

Thin-Film Group, Universidad del Valle Cali, Colombia

Received 29.11.13

Tribology Polymers, Powder Metallurgy

and Processing of Solid Recycled Research Group

Universidad del ValleCali, Colombia, USA

BiologicsResearch, Biotechnology Center of Excellence,

Janssen R\&D, LLC, Pharmaceutical Companies of Johnson \& Johnson, Spring House, PA, USA

National Biotechnology \& Pharmaceutical Association, Chicago, USA

Bioengineering Research Group, Nanotechnology

and Advanced Materials Department,

Materials and Energy Research Center (MERC), Tehran, Iran 